\title{
Föräldraidentiteter som skapas och formas under inskolningen i förskolan
}

Maria Simonsson

The self-archived postprint version of this journal article is available at Linköping University Institutional Repository (DiVA):

http:/ / urn.kb.se/ resolve?urn=urn:nbn:se:liu:diva-146210

N.B.: When citing this work, cite the original publication.

Simonsson, M., (2018), Föräldraidentiteter som skapas och formas under inskolningen i förskolan, Venue, (7), 1-6.

Original publication available at: https:// old.liu.se/ uv/ lararrummet/venue

Copyright: The Author

URL: https:// old.liu.se/ uv/lararrummet/venue 


\title{
Föräldraidentiteter som skapas och formas under inskolningen i förskolan
}

\author{
Maria Simonsson, Linköpings universitet
}

Förskolestarten börjar med inskolning. Den här tiden är en omvälvande period inte bara för barnet utan för hela familjen. Vårdnadshavarna måste lära sig att bli trygga förskoleföräldrar, att hjälpa sitt barn under inskolningen, att bidra med kunskaper om barnet och att hjälpa pedagogerna att tolka barnets beteende och önskningar under inskolningen.

\section{Introduktion}

Internationellt har den svenska förskolan, med dess barncentrerade pedagogik, lyfts fram som unik och världsledande. De allra flesta barn i åldrarna ett-fem år inkluderas i någon form av förskoleverksamhet, som därmed införlivas i den moderna svenska barndomen.

I Sverige, likt i många andra länder, har föräldrars/vårdnadshavarnas involverande i barnens utbildning blivit en allt viktigare fråga för såväl politiker som de professionella för att kunna realisera målen med utbildningen. Detta speglas även i det nationella styrdokumentet för förskolan (Skolverket, 2016) som dels betonar förskollärarnas uttalade ansvar för föräldrasamverkan och dels markerar föräldrarnas möjligheter att involvera sig i och samverka med de professionella i verksamheten (Skolverket, 2017).

I denna artikel presenteras några delresultat från en större forskningsstudie gällande förskolepersonalens resonemang kring föräldraaktiv inskolning (3-5 dagar).

I förskolan förekommer vanligtvis två olika inskolningsmetoder, dels den som vi kan kalla den traditionella inskolningen som varar under 14 dagar, och dels den föräldraaktiva inskolningen som också kallas för 3-5 dagars inskolning. Den sistnämnda metoden har kommit att användas mer och mer av förskolepersonalen.

Vi behöver ha mer kunskaper om hur förskollärarna resonerar kring föräldrarnas involverande i verksamheten, när de träder in som en "ny medverkande aktör" på personalens realiseringsarena. Sju förskolearbetslag i Mellansverige har tillfrågats att delta i denna studie och de har diskuterat den föräldraaktiva inskolningen i fokusgruppsintervjuer. Dessa arbetslag har arbetat flera år med denna inskolningsmetod. Några av dem erbjuder också vårdnadshavarna att bestämma vilken inskolningsmetod (den traditionella, cirka 14 dagar, eller den föräldraaktiva, 3-5 dagar) de önskar för sina barn. 
I denna artikel fokuseras på vilka typer av föräldraidentiteter som skapas i samtal med förskollärare om föräldraaktiv inskolning samt vilka önskvärda förskoleföräldrapositioner som framträder.

\section{Inskolning och föräldrar}

Inskolningen är en värdefull praktik för alla de inblandade aktörerna, såväl familjen och förskolepersonalen, för att skapa och utveckla relationen mellan hem och förskola. Detta uttrycks även i förskolans styrdokument (Skolverket, 2016, 2017) där det lyfts fram att förskolan ska erbjuda barnet och vårdnadshavarna en god introduktion, som ger grunden för det långa samarbetet mellan hemmet och förskolan.

Skandinavisk forskning har utifrån ett historiskt perspektiv uppmärksammat att det har skett en förändring då det gäller förskolans roll gentemot hem och familj (Tallberg Broman 2013). Flera svenska studier vittnar om att förskolepersonalen i olika sammanhang förväntar sig ett samarbete med föräldrarna (Markstöm \& Simonsson 2017; Simonsson \& Markström 2013; Tallberg Broman \& Persson 2002). Det växer också fram, eller snarare formas, praktiker där föräldrarna får medverka mer aktivt än tidigare. Ett exempel på en sådan är inskolningen i förskolan. Fastän alla barn genomgår inskolningsaktiviteter med sina föräldrar i förskolan är dessa sällan studerade utifrån samarbetet mellan föräldrarna och pedagogerna. Fokus har i stället framför allt varit riktat mot barnen (Månsson 2013; Simonsson \& Thorell 2010; Simonsson 2015).

\section{Att styra föräldrar under inskolningen}

Analyserna av fokusgruppsintervjuerna visar på en tydlig förändring i hur personalen ser på föräldrars positioner under inskolningen. När personalen diskuterar föräldrars engagemang i den traditionella inskolningen (14 dagar) beskrivs att föräldrarna ofta är passiva under inskolningen. De är tillsammans med barnen under korta perioder på förskolan där de sedan "tar ett steg" tillbaka för att pedagogen och barnet själva ska skapa en relation och att barnet ska kunna knyta an till pedagogen.

I den föräldraaktiva inskolningen har, enligt informanterna, däremot föräldrarna en mycket mer aktiv position, där de tillsammans med barnet deltar i förskolans aktiviteter och bekantar sig med förskolans miljö. Här är det också familjen, dvs både barnet och föräldrarna, som tillsammans skapar relationer till förskolepersonalen och de andra barnen. Pedagogerna beskriver att det är viktigt att föräldrarna är medvetna om detta aktiva förhållningssätt och att de följer sina barn under typiskt klockan 9-14 på inskolningsdagarna. Detta innebär att föräldrarna ansvarar för barnens omsorg och lärande under inskolningen, dvs det uttalas tydligt att det är föräldrarnas uppgift att tillgodose barnets behov av stöd för att klara av det dagliga livet i förskolan. 
Vi kan tolka resultaten som att personalen utövar en "mjuk styrning" ("soft gouvernace") (Bartholdsson, 2007) av föräldrarna för att dessa ska inta de önskade positionerna under inskolningen, dvs att de guidas till att vara aktiva under sina barns inskolning (se bild 1).

Föräldrars positioner under familjeaktiv inskolning

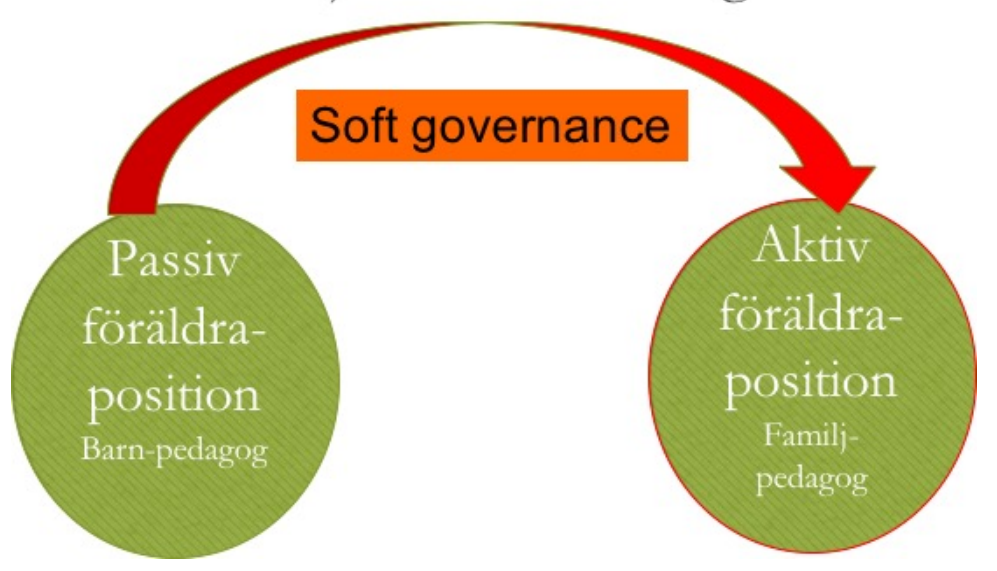

Bild 1: Styrning av föräldrarna under inskolningen

Om de inte är tillräckligt aktiva korrigeras deras beteenden genom att personalen påtalar hur de ska agera under inskolning. Att vara passiv under inskolningen är inte ett önskvärt beteende hos föräldrarna enligt pedagogerna.

\section{Föräldraidentiteter under inskolning}

Denna studie kring föräldraaktiv inskolning visar att det är ett komplext fenomen, som kan sägas utgöra en arena för bland annat konstruktion av olika föräldraidentiteter. I förskollärarnas samtal kunde tre olika föräldrasubjektspositioner identifieras: Lärandeposition, Trygghetsposition, och Team work-position.

\section{Att bli förskoleföräldrar - en lärandeposition}

När föräldrarna kommer till förskolan för första gången har många av dem inte varit i kontakt med förskolans värld tidigare. Några arbetslag betonar att inskolningen inte enbart är till för barnen utan det är också till för föräldrarna.

Ida: För det är lika mycket inskolning för föräldrar som det är för barn tycker jag, speciellt med dagens yngre föräldrar, som inte, de kanske varit på förskolan själva ... för det har hänt, sådan markant skillnad, sedan de var här, så jag tycker det är inskolning för föräldrar med ... lära känna oss ... det är ett givande och tagande föräldrar och oss emellan, och sen är det att lära känna barnet. 
Elin: ja, och sen ... sen våra nysvenska familjer också, för dom att ha den möjligheten att skolas in dom också ... och se ... då kommer vi raskt in på den metod vi använder nu, den ... den är föräldraaktiv, då făr de verkligen en möjlighet att se vad det här är ... vara med från morgon till eftermiddag ... över hela dagen ... jättebra.

Utöver att skola in barnen får föräldrarna under denna period också möjlighet att lära känna förskolans miljö, personalen, de andra barnen och deras föräldrar, dvs förskolans aktörer, samtidigt som de får inblick i förskolans verksamhet. Detta är en ömsesidig process där man lär av varandra och gemensamt skapar en bild av barnet och dess behov. Den föräldraaktiva inskolningsmetoden är alltså gynnsam för att konkret visa på hur vardagen "görs" och för nysvenska familjer kan denna metod vara fördelaktig då de snabbt kan få en överblick över det svenska förskolesystemet.

\section{Trygga föräldrar - trygghetsposition}

Trygga föräldrar är viktiga under inskolningen oavsett vilken metod man använder och detta är naturligtvis ingen nyhet. Dock betonar arbetslagen i denna studie de olika aspekterna av föräldrars trygghet och hur den tryggheten skapas.

Ellen: Jag tror att föräldrarna är tryggare, för de vet hur det fungerar. Hur vi är. För de ser hur vi är med de andra barnen. Trygga föräldrar är jätteviktigt för barnen.

Genom att föräldrarna deltar i förskolans verksamhet under en längre tid av dagen blir de medvetna om vad som pågår där. Just denna kunskap är avgörande, menar pedagogerna, för att kunna visualisera vardagen, rutinerna samt personalens förhållningssätt till barnen. De får se den vardagliga verksamheten inifrån. Ett av arbetslagen utryckte även att föräldrarna under den traditionella inskolningen (14-dagars) enbart får insyn i en mycket begränsad del av förskolans verksamhet samt att förskollärarna specialarrangerar inskolningen för det individuella barnet. Det har också framkommit att alla föräldrar inte är förberedda för barnets transition från hemmabarn till förskolebarn (Markström \& Simonsson 2017).

\section{Team work-position}

Av fokusgruppsintervjuerna framkommer att personalen anser att de och föräldrarna ska lära sig av varandra. Föräldrarna ska informera och lära personalen om barnets vanor, hur det reagerar i olika situationer etc. "Vi måste lyssna på föräldrarna, vad de berättar för oss ... små barn kan inte tala för sig själva", säger en av förskollärarna. Pedagogerna betonar här föräldrarnas viktiga roll i samarbetet kring barnets bästa. De bidrar till arbetslagets lärande om barnet och familjen. Föräldrarna deltar också i tolkningsprocesserna av barnets uttryck och beteende under inskolningen på förskolan. Denna kunskapsproduktion är avgörande för pedagogerna i deras arbete vad gäller transitionen av barnet från att vara ett hemmabarn till att bli ett förskolebarn. 
Sammanfattningsvis framkommer i samtalen, när arbetslagen i förskolan samtalar om inskolningsmetoder, att under den föräldraaktiva inskolningen skapas önskvärda föräldraidentiteter och formas kompetenta föräldrapositioner, vilka är möjliga att inta för dem. Om de intar andra positioner korrigeras de av pedagogerna, dvs det påtalas vad det innebär att vara aktiv under inskolningen. För att kunna realisera den goda barndomen i förskolan förutsätts att förskolans aktörer, dvs förskolepersonalen och föräldrarna, är kompetenta och kunniga i sina roller. Det är också viktigt att de kan utföra sina uppgifter på ett sådant sätt att de kan vara parter i samarbetet och förhandlingarna kring barnets bästa.

\section{Implikationer}

Utifrån studiens resultat måste föräldraaktiv inskolning i förskolan ses som ett komplext fenomen, där olika aktörer gemensamt verkar för barnets bästa. Pedagogerna förväntar sig att föräldrarna är trygga i sin föräldraroll, så att de fullt ut ska kunna bli involverade i sitt barns inskolning. För pedagogerna är det också viktigt att föräldrarna snabbt kan koda av vad som krävs för att bli "kompetenta" förskoleföräldrar, för att på bästa sätt kunna bidra under inskolningen.

För vårdnadshavarna är det viktigt att uppmärksamma att de har flera uppgifter under inskolningen, nämligen

a) att guida sitt barn under inskolningen i förskolan.

b) att introducera sitt barn för förskolans aktörer

c) att hjälpa pedagogerna att tolka barnets önskemål och behov, samt sist men inte minst

d) att lära sig att bli förskoleföräldrar.

Det som blir uppenbart är att vårdandshavarna tidigt bör informeras om vad som förväntas av dem.

Slutligen är det viktigt att uppmärksamma att den föräldraaktiva inskolningen inte passar alla barn, och att det finns stora variationer kring hur barn kan skolas in och knyta an till pedagogerna i förskolan. Återigen blir det tydligt att vårdnadshavarna har en viktig roll i barnens övergång mellan hemmet och förskolan.

\section{Referenser}

Bartholdsson, Å. (2007). Med facit i hand: normalitet, elevskap och vänlig maktutövning i två svenska skolor. Akademisk avhandling. Stockholm universitet. Antropologiska institutionen.

Markström, A.-M., \& Simonsson, M. (2017). Introduction to preschool : strategies for managing the gap between home and preschool. Nordic Journal of Studies in Educational Policy, 1-10. https://doi.org/10.1080/20020317.2017.1337464

Månsson, A. (2013). Familjens inskolning i förskolan- ett rum för möjligheter. I A. Harju \& I. Tallberg Broman. (Red). Föräldrar, förskola och skola, s.79-94 Om mångfald, makt och möjligheter. Lund: Studentlitteratur.

Simonsson, M. (2018). Changing Subject Positions of the Parents During the Introduction to the Swedish Preschool. I Sixteenth Annual Hawaii International Conference on Education (Vol. 1, s. 153-153). Honolulu 
Simonsson, M. (2015). The role of artifacts during transition into the peer group: 1-to 3-year-old children's perspective on transition between the home and the preschool in Sweden. International Journal of Transitions in Childhood, 8, 14-24.

Simonsson, M., \& Karlsson, I. (2013). A New Pedagogic Practice in Introduction to the Swedish Preschool: Changing Subject Positions (s. 230-231). Presenterad vid Joint "7th SELF Biennial International Conference" and "ERAS Conference", 9-11 September 2013, Singapore.

Simonsson, M. \& Markström, A-M. (2013). Utvecklingssamtalet som uppgift och verktyg i förskollärarnas professionssträvanden i interaktion med föräldrar. Nordisk Barnehageforskning, 6(12), 1-18. .doi.org/10.7577/nbf.355

Simonsson, M. \& Thorell, M. (2010). Att börja på förskolan. Exemplet på barns sociala samspel under inskolningen. Educare, 1, 53-73. http://hdl.handle.net/2043/10531

Skolverket (2016). Läroplan för förskolan Lpfö 98. [Ny, rev. utg.]. Stockholm: Skolverket.

Skolverket (2017). Måluppfyllese i förskolan. Skolverkets allmänna råd med kommentarer. Stockholm: Skolverket.

Tallberg Broman, I. (2013). Föräldrasamverkan i förändring. I A. Harju \& I. Tallberg Broman. (Red.) Föräldrar, förskola och skola. Om mångfald, makt och möjligheter. Lund: Studentlitteratur. 